\title{
Serial measurement of plasma arginine vasopressin in the newborn
}

\author{
N McINTOSH AND A SMITH \\ Department of Child Health, St George's Hospital Medical School, London
}

SUMMARY Plasma arginine vasopressin was measured serially in 11 preterm infants and one asphyxiated, term infant. The samples were taken through umbilical arterial catheters placed at birth for blood gas measurements because ventilatory support was required. Plasma samples of 200 to $300 \mu \mathrm{l}$ were taken 4 to 12 hourly for up to 100 hours after birth. Plasma arginine vasopressin was measured by a cytochemical bioassay. A significant correlation between plasma arginine vasopressin and plasma osmolality was found in only two out of six infants. The normal 'resting' concentration was between 0.5 and $2 \mathrm{pg} / \mathrm{ml}$. In five infants, apparent bursts of arginine vasopressin secretion were seen, and in one spontaneously breathing infant with respiratory distress, continuously high concentrations ( 12 to $25 \mathrm{pg} / \mathrm{ml}$ ) were recorded over the first 100 hours.

In the healthy, term neonate, water homeostasis is maintained with reasonable efficiency, even though renal immaturity precludes a degree of control comparable with that of older children and adults. ${ }^{1}$ The sick neonate, however, has problems retaining fluid at times of reduced water intake and of excreting excess if overloaded. ${ }^{1}$ Fluid intake in the sick and preterm infant is likely to be regulated by the care giver, without much appreciation of the physiological control.

The posterior pituitary peptide hormone, arginine vasopressin, is the major antidiuretic hormone in man. Although concentrations in human umbilical cord blood have been extensively reported, there have been only isolated measurements of arginine vasopressin in the peripheral blood of term and preterm neonates.2-6 Consequently, little is known about the efficiency of the normal control that is exerted by the hypothalamo-neurohypophyseal axis on water homeostasis in the newborn.

The lack of data on plasma arginine vasopressin concentrations in neonates, stems from the apparently very low circulating concentrations of the hormone and the relative insensitivity of established assay systems. These together lead to the requirement for 2 to $5 \mathrm{ml}$ of blood for extraction and measurement of the hormone. The aim of this study was to use a highly sensitive cytochemical bioassay to investigate the arginine vasopressin concentrations in serial plasma samples obtained from sick term and preterm infants, and to endeavour to correlate the results with the clinical status of the child.

\section{Materials and methods}

Eleven preterm infants, with gestational ages of 26 to 34 weeks, and one term infant were studied in the neonatal unit at this hospital. All the clinical data relating to the condition of these infants are given in Table 1.

Approximately $0.5 \mathrm{ml}$ blood samples were obtained via an umbilical catheter placed in the first few hours of life for blood gas and arterial blood pressure monitoring. After the dead space in the system had been discarded, the blood was drawn into a heparinised plastic syringe, quickly transferred to $1.5 \mathrm{ml}$ polypropylene reaction tube, and immediately centrifuged at room temperature in a Beckman Microfuge at approximately $10^{4} \times g$ for one minute. The plasma (approximately $300 \mu \mathrm{l}$ ) was immediately snap frozen in liquid nitrogen and stored at $-70^{\circ} \mathrm{C}$ until assayed.

The routine monitoring of these infants consisted of an indwelling umbilical arterial oxygen electrode, transcutaneous oxygen electrode, continuous heart rate monitoring, continuous blood pressure measurement with a transducer on the umbilical arterial catheter, and specific gravity of every urine sample passed (refractometer). The ventilated infants were managed on Bournes BP 200 ventilators. Peak airway pressure and expiratory pressure or 
Table 1 Details of 11 preterm infants with respiratory distress syndrome and one term infant with birth asphyxia in whom plasma arginine vasopressin concentrations were measured

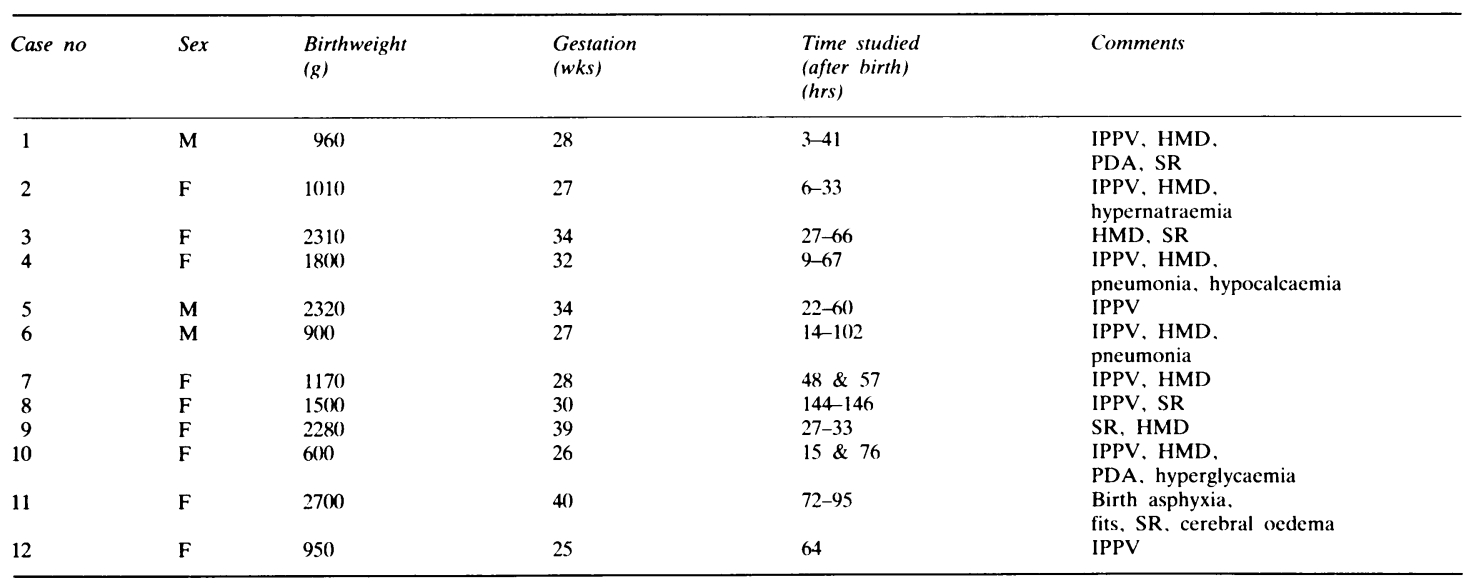

$\mathrm{IPPV}=$ intermittent positive pressure ventilation; $\mathrm{HMD}=$ hyaline membrane disease; $\mathrm{SR}=$ spontaneous respiration; $\mathrm{PDA}=$ patent ductus arteriosus.
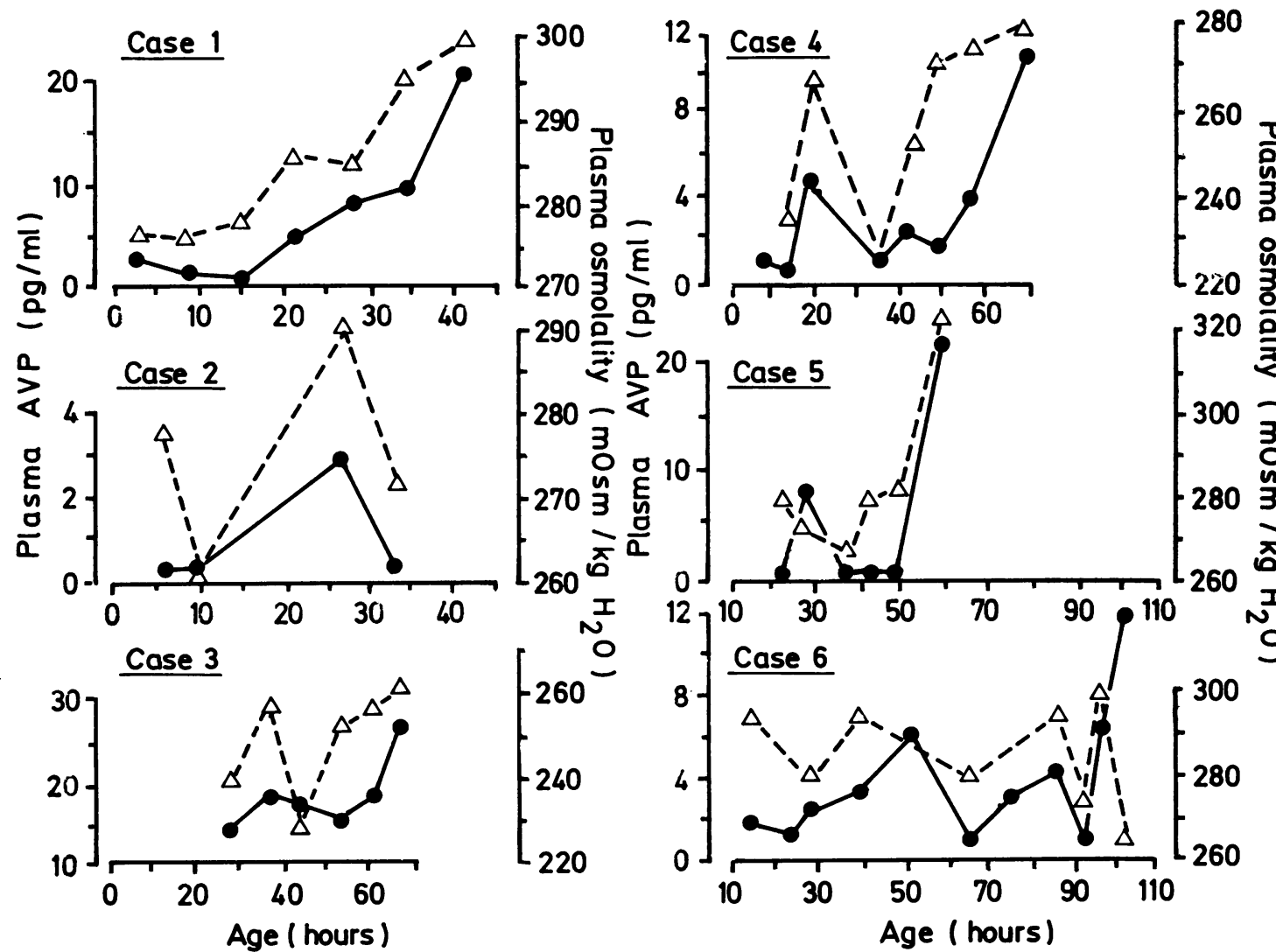

$\underbrace{I}$
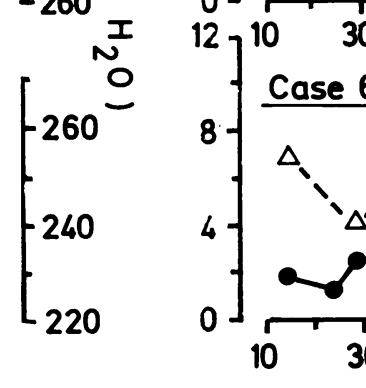

Case 6

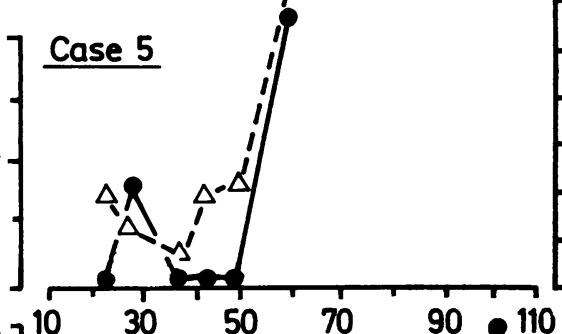


continuous positive airway pressure, ratio of inspiration to expiration, and ventilator rate were noted at hourly intervals, and a mean airway pressure was

Table 2 Relation between plasma arginine vasopressin $(A V P)$ concentrations and plasma osmolality and urine specific gravity (USG) with increasing age in preterm infants

\begin{tabular}{|c|c|c|c|c|c|}
\hline $\begin{array}{l}\text { Case } \\
\text { no }\end{array}$ & $\begin{array}{l}\text { Age } \\
\text { (hrs) }\end{array}$ & $\begin{array}{l}\text { USG } \\
(\times 1000)\end{array}$ & $\begin{array}{l}\text { Plasma } \\
\text { osmolality } \\
\text { (mOsm/ } \\
\left.\mathrm{kg} \cdot \mathrm{H}_{2} \mathrm{O}\right)\end{array}$ & $\begin{array}{l}\text { Plasma AVP } \\
\text { concentration } \\
(p g / m l)\end{array}$ & $r^{*}$ \\
\hline 1 & $\begin{array}{r}3 \\
9 \\
15 \\
21 \\
28 \\
34 \\
41\end{array}$ & $\begin{array}{l}1005 \\
1005 \\
1005 \\
1005 \\
1010 \\
1009 \\
1012\end{array}$ & $\begin{array}{l}276 \\
276 \\
278 \\
286 \\
285 \\
295 \\
300\end{array}$ & $\begin{array}{r}2.8 \\
1.2 \\
0.2 \\
5.0 \\
7.9 \\
9.4 \\
20.0\end{array}$ & $\begin{array}{l}r=0.92 \\
(P=0.005)\end{array}$ \\
\hline 2 & $\begin{array}{r}6 \\
10 \\
27 \\
33\end{array}$ & $\begin{array}{l}1005 \\
1009 \\
1008 \\
1008\end{array}$ & $\begin{array}{l}278 \\
260 \\
291 \\
272\end{array}$ & $\begin{array}{l}0 \cdot 2 \\
0 \cdot 2 \\
3 \cdot 0 \\
0 \cdot 4\end{array}$ & $\begin{array}{l}r=0.82 \\
(P>0 \cdot 05)\end{array}$ \\
\hline 3 & $\begin{array}{l}27 \\
37 \\
43 \\
53 \\
60 \\
66\end{array}$ & $\begin{array}{l}1010 \\
1003 \\
1006 \\
1007 \\
1006 \\
1006\end{array}$ & $\begin{array}{l}240 \\
260 \\
230 \\
254 \\
258 \\
263\end{array}$ & $\begin{array}{l}14.5 \\
18.5 \\
17.5 \\
15.5 \\
18.0 \\
26.6\end{array}$ & $\begin{array}{l}r=0.54 \\
(P>0.05)\end{array}$ \\
\hline 4 & $\begin{array}{r}9 \\
14 \\
20 \\
35 \\
43 \\
49 \\
57 \\
67\end{array}$ & $\begin{array}{l}1006 \\
1007 \\
1007 \\
1002 \\
1002 \\
1002 \\
1002 \\
1005\end{array}$ & $\begin{array}{l}- \\
233 \\
268 \\
227 \\
253 \\
271 \\
274 \\
279\end{array}$ & $\begin{array}{r}0.9 \\
0 \cdot 6 \\
4.9 \\
1.0 \\
2.4 \\
1.5 \\
3.8 \\
10.7\end{array}$ & $\begin{array}{l}r=0.67 \\
(P>0.05)\end{array}$ \\
\hline 5 & $\begin{array}{l}22 \\
26 \\
38 \\
43 \\
48 \\
60\end{array}$ & $\begin{array}{l}1008 \\
1012 \\
1006 \\
1005 \\
1006 \\
1006\end{array}$ & $\begin{array}{l}278 \\
272 \\
266 \\
279 \\
280 \\
322\end{array}$ & $\begin{array}{r}0.3 \\
8 \cdot 3 \\
0.5 \\
0.2 \\
0.2 \\
22 \cdot 0\end{array}$ & $\begin{array}{l}r=0.87 \\
(P<0.05)\end{array}$ \\
\hline 6 & $\begin{array}{r}14 \\
22 \\
27 \\
38 \\
51 \\
65 \\
74 \\
86 \\
92 \\
96 \\
102\end{array}$ & $\begin{array}{l}1015 \\
1015 \\
1005 \\
1008 \\
1010 \\
1010 \\
1005 \\
1008 \\
1005 \\
- \\
1012\end{array}$ & $\begin{array}{l}294 \\
281 \\
295 \\
- \\
280 \\
\overline{295} \\
273 \\
300 \\
265\end{array}$ & $\begin{array}{r}1.8 \\
1.2 \\
2.5 \\
3.3 \\
5.8 \\
0.7 \\
3.0 \\
4.6 \\
0.6 \\
6.3 \\
11.9\end{array}$ & $\begin{array}{l}r=0 \cdot 25 \\
(P>0 \cdot 05)\end{array}$ \\
\hline 7 & $\begin{array}{l}48 \\
57\end{array}$ & $\begin{array}{l}1009 \\
1010\end{array}$ & $\begin{array}{l}267 \\
267\end{array}$ & $\begin{array}{l}7 \cdot 7 \\
6 \cdot 4\end{array}$ & \\
\hline 8 & $\begin{array}{l}144 \\
145 \\
146\end{array}$ & $\begin{array}{l}\overline{-} \\
1006\end{array}$ & $\begin{array}{l}291 \\
307 \\
288\end{array}$ & $\begin{array}{l}0.6 \\
0.2 \\
0 \cdot 2\end{array}$ & \\
\hline 9 & $\begin{array}{l}27 \\
33\end{array}$ & $\begin{array}{l}1006 \\
1005\end{array}$ & $\begin{array}{l}292 \\
297\end{array}$ & $\begin{array}{l}7.3 \\
7.6\end{array}$ & \\
\hline 10 & $\begin{array}{l}15 \\
76\end{array}$ & $\begin{array}{l}1022 \\
1015\end{array}$ & $\begin{array}{l}327 \\
292\end{array}$ & $\begin{array}{l}1.4 \\
0.5\end{array}$ & \\
\hline 11 & $\begin{array}{l}72 \\
79 \\
84 \\
95\end{array}$ & $\begin{array}{l}1012 \\
1006 \\
1006 \\
1008\end{array}$ & $\begin{array}{l}270 \\
\frac{2}{275} \\
273\end{array}$ & $\begin{array}{l}1.2 \\
0.8 \\
1 \cdot 7 \\
0.4\end{array}$ & \\
\hline 12 & 64 & 1016 & 261 & 0.5 & \\
\hline
\end{tabular}

$\mathrm{r}=$ linear correlation coefficient between plasma AVP and plasma osmolality. calculated. Blood gases and chest radiographs were performed at variable intervals depending on clinical indications. Plasma osmolality was measured on each sample using a vapour pressure microsmometer (Wescor Inc, USA). Plasma arginine vasopressin was measured by a cytochemical bioassay described previously. ${ }^{7}$ Ethical sanction for the project was obtained from St George's Hospital Ethical Committee.

\section{Results}

The plasma arginine vasopressin and osmolality and urine specific gravity measurements with the age of the baby are shown in Table 2. Correlation between the plasma arginine vasopressin concentration and plasma osmolality was determined only when at least four values for each were obtained for the infant. There is a significant correlation between plasma arginine vasopressin concentration and plasma osmolality in cases 1 and $5 \quad(r=0.92$, $\mathrm{P}=0.005$; and $\mathrm{r}=0.87, \mathrm{P}<0.05$ respectively). Nonsignificant correlations $(P>0.05)$ were obtained in cases $2,3,4$, and $6(r=0.82,0.54,0.67$, and 0.25 respectively). The data from each of these babies is represented graphically in the Figure. No correlation could be found between any of the clinical parameters monitored and the plasma arginine vasopressin concentrations in any of the infants investigated. A full table of all data with the age of the baby is available from the authors by request.

Plasma arginine vasopressin concentrations ranged from 0.16 to $26.6 \mathrm{pg} / \mathrm{ml}$ with a median of 2.43 $\mathrm{pg} / \mathrm{ml}$. Plasma osmolality ranged from 227 to 327 $\mathrm{mOsm} / \mathrm{kg} \cdot \mathrm{H}_{2} \mathrm{O}$ with a median of $276 \mathrm{mOsm} /$ $\mathrm{kg} \cdot \mathrm{H}_{2} \mathrm{O}$. In four infants (cases 2, 4, 5, and 6) there were intermittent peaks of plasma arginine vasopressin activity; on several occasions rising above 9 $\mathrm{pg} / \mathrm{ml}$. In one infant (case 3), who was breathing spontaneously throughout the study, there was a persistent, very high plasma arginine vasopressin concentration of 14.5 to $26 \cdot 6 \mathrm{pg} / \mathrm{ml}$.

All infants except case 10 survived. This baby developed necrotising enterocolitis and septicaemia at 3 weeks of age.

\section{Discussion}

Plasma arginine vasopressin concentrations have been shown to be highest in cord blood and fall rapidly in the first 24 hours of life, with a continuing fall over the first week, and then a rise to adult values (approximately 2 to $4 \mathrm{pg} / \mathrm{ml}$ ) thereafter. ${ }^{245}$ The serial data presented in this study show no trends in the concentration during the first 24 hours, or in the first few days of life in any of the infants 
investigated. The median plasma arginine vasopressin concentration in this study was well within the range seen in normal adults and was also similar to the other published data in the newborn using radioimmunoassay. ${ }^{258}$ Although most values were in the normal range, values as high as $26 \mathrm{pg} / \mathrm{ml}$ were observed. The cross sectional study by Rees $e t a l$ in preterm infants with respiratory distress syndrome also showed large variations in plasma concentrations, with a maximum of approximately $30 \mathrm{pg} / \mathrm{ml} .^{5}$ In two infants, for whom enough serial data were available, we were able to show a strong correlation between plasma arginine vasopressin and the plasma osmolality (Figure). This is in contrast to the radioimmunoassay data of Rees et al who could find no such correlation. ${ }^{5}$ Although the four other serially sampled infants in our study did not show correlations reaching statistical significance, the regression suggested that this might be due to insufficient numbers of samples. In one infant in this study (case 10) very high plasma and urine osmolalities were seen, but circulating plasma arginine vasopressin concentrations were persistently low, this cannot be explained. No infants in our study were overtly hypotensive or hypovolaemic, thus we have no evidence to establish directly whether volume receptors are effective in the preterm infant. Rees et al, using urinary arginine vasopressin measurements, have shown that it is likely that the volume mechanism is functional. ${ }^{9}$

We know of only one previous study measuring serial plasma arginine vasopressin concentrations in the newborn. Speer et al showed raised plasma concentrations in term infants with birth asphyxia, and were able, with 12 hourly measurements, to show that these high concentrations fell to normal by the third day. ${ }^{10}$ We believe that the data presented in our study are the first serial plasma measurements reported in the preterm neonate.

Stresses such as asphyxia, ${ }^{11}$ meningitis, ${ }^{12}$ respiratory infections,${ }^{13}$ pneumothorax,${ }^{14}$ and intracranial and intraventricular haemorrhage, ${ }^{15}$ all of which are common in the preterm newborn, are recognised as leading to excessive secretion of arginine vasopressin in the absence of the normal physiological stimuli (syndrome of inappropriate antidiuretic hormone secretion). In five infants in our study, occasional bursts of arginine vasopressin secretion were observed which could not be correlated with any of the clinical parameters monitored. The infants all had respiratory distress, but by generally accepted management standards none were hypoxic or hypovolaemic and none developed pneumothoraces during the study. No infants in the study had a clinical intraventricular haemorrhage, but as serial intracranial ultrasound was not being performed, we have not excluded the possibility of small intraventricular haemorrhages leading to release. ${ }^{15}$ It is possible that the release of arginine vasopressin was related to the stress of painful stimuli, ${ }^{16}$ as the babies were on ventilators. It is important to note that the surges of arginine vasopressin secretion shown were short lived and that even with the relative frequency of sampling of infants in this study, it is possible that some bursts of secretion may have been missed. Rees et $a l,{ }^{17}$ measuring serial urinary concentrations, also showed bursts of arginine vasopressin excretion in the preterm infant. In some cases only could these be associated with the development of pneumothorax, mask ventilation, or intraventricular haemorrhage.

Although it has been reported that positive pressure ventilation may induce the inappropriate secretion of arginine vasopressin, ${ }^{18}{ }^{19}$ it is noteworthy that the highest plasma concentrations seen in this study were in the spontaneously breathing infant (case 3,14 to $26 \mathrm{pg} / \mathrm{ml}$ ). This infant was not hypotensive or hypovolaemic. The dilute plasma osmolality and very high arginine vasopressin concentration suggested the diagnosis of syndrome of inappropriate antidiuretic hormone secretion, but urine specific gravities were persistently low. The formal criteria for the diagnosis of this syndrome could therefore only be invoked by presuming that the specific gravities were not maximally low. The condition would otherwise seem to be an end organ insensitivity to arginine vasopressin, possibly with an intact feedback.

Due to its cumbersome nature, the cytochemical bioassay for plasma arginine vasopressin can only be used for the retrospective evaluation of neonatal fluid balance, the results coming too late for direct action to be taken on the infant concerned. If any assay for plasma arginine vasopressin is going to be important in the management of the newborn, it will not only need to be as sensitive as the cytochemical assay, but also relatively rapid to perform.

This work was supported by a grant from Action Research, the National Fund for Research into Crippling Diseases. We would also like to thank Mrs V Williams and Mrs C Ryan for their assistance in the preparation of this paper.

\footnotetext{
References

1 Edelman CM, Spitzer A. The kidney. In: Smith CA, Nelson MN, eds. The physiology of the newborn infant. 4th ed. Illinois: Thomas, 1976:416-59.

2 Hoppenstein JM, Miltenberger FW, Moran WH. The increase in blood levels of vasopressin in infants during birth and surgical procedures. Surg Gynecol Obstet 1968;127:966.

3 Hadeed AJ, Leake RD, Weitzman RE, Fisher DA. Possible mechanisms of high blood levels of vasopressin during the neonatal period. J Pediatr 1979;94:805-8.
} 
${ }^{4}$ Polin RA, Husain MK, James LS, Frantz AG. High vasopressin concentrations in human umbilical cord blood. Lack of correlation with stress. J Perinat Med 1977;5:114-9.

5 Rees LH, Forsling ML, Brook CGD. Vasopressin concentrations in the neonatal period. Clin Endocrinol 1980;12:357-62.

${ }^{6}$ Leake RD, Artman HG, Fisher DA. Plasma arginine-vasotocin (AVT) in newborn infants. Pediatr Res 1982;16:114A.

7 Smith A, McIntosh N. Specificity of a cytochemical assay for arginine-vasopressin and its validation for plasma measurement. Biosci Rep 1984;4:100-14.

${ }^{8}$ Robertson GL. The regulation of vasopressin function in health and disease. Recent Prog Horm Res 1977;33:333-85.

9 Rees LH, Brook CGD, Forsling ML. Continuous urine collection in the study of vasopressin in the newborn. Horm Res 1983;17:134-40.

${ }^{10}$ Speer ME, Gorman WA, Kaplan SL, Rudolph AJ. Elevation of plasma concentrations of arginine-vasopressin following perinatal asphyxia. Acta Paediatr Scand 1984;73:610-4.

${ }^{11}$ Khare SK. Neurohypophysial dysfunction following asphyxia. J Pediatr 1977;90:628-9.

12 Reynolds DW, Dweck HS, Cassady G. Inappropriate antidiuretic secretion in a neonate with meningitis. Am J Dis Child 1972;123:251-3.
${ }^{13}$ Rivers RPA, Forsling ML, Olver RP. Inappropriate secretion of ADH in infants with respiratory infections. Arch Dis Child 1981;56:358-63.

${ }^{14}$ Stern P, LaRochelle FT, Little GA. Vasopressin and pneumothorax in the neonate. Pediatrics 1981;68:499-503.

15 Adams JM, Kenny JA, Rudolph AJ. Central diabetes insipidus following intraventricular haemorrhage. $J$ Pediatr 1976;88:292.

16 Kendler KS, Weitzman RE, Fisher DA. The effect of pain on plasma AVP concentrations in man. Clin Endocrinol 1978;8: 89-94.

17 Rees L, Brook CGD, Shaw JCL, Forsling ML. Hyponatraemia in the first week of life in preterm infants. Part I. Arginine vasopressin secretion. Arch Dis Child 1984;59: 414-22.

18 White WA, Bergland RM. Experimental inappropriate antidiurective hormone secretion caused by positive pressure ventilators. J Neurosurg 1972;36:608.

${ }^{19}$ Svenningsen NW, Andreasson B, Lindworth M. Diuresis and urine concentration during CPAP in newborn infants. Acta Paediatr Scand 1984;73:727.

Correspondence to Dr Neil McIntosh, Department of Child Health, St George's Hospital Medical School, London SW17 0RE.

Received 4 June 1985 